Article

\title{
Linguistic Diversity as a Challenge for Street-Level Bureaucrats in a Monolingually-Oriented Organisation
}

\author{
Elisabeth Scheibelhofer *, Clara Holzinger and Anna-Katharina Draxl \\ Department of Sociology, University of Vienna, 1010 Vienna, Austria; E-Mails: elisabeth.scheibelhofer@univie.ac.at (E.S.), \\ clara.holzinger@univie.ac.at (C.H.), anna-katharina.draxl@univie.ac.at (A.-K.D.) \\ * Corresponding author
}

Submitted: 30 July 2020 | Accepted: 28 September 2020 | Published: 14 January 2021

\begin{abstract}
Migration-induced diversity has led to the global emergence of multilingual life worlds in which language regimes are particularly intertwined with labour markets. Thus, state institutions such as national unemployment services must fulfil a special role in society. In a qualitative research project (2019-2021), we interviewed employees at the Austrian Public Employment Service (AMS) at multiple organisational levels. The results demonstrate diverging and (apparently) contradicting approaches and strategies throughout the organisation concerning the appropriateness of using German exclusively during interactions with clients. This is illustrated along a continuum, ranging from a reflective, critical approach towards linguistic diversity that is at least partly based on ideas promoting the value of multilingualism to frequently encountered notions of the need for monolingualism. Such a framework must be understood by considering the coexistence of diverging ideas and ideologies surrounding multilingualism, as well as a neoliberal working context characterised by new public management and activation policy.
\end{abstract}

\section{Keywords}

communication; labour-market integration; language regimes; language-based discrimination; linguistic diversity; migration; social security; street-level bureaucracy; public employment service

\section{Issue}

This article is part of the issue "Social Inclusion and Multilingualism: The Impact of Linguistic Justice, Economy of Language and Language Policy" edited by László Marácz (University of Amsterdam, The Netherlands / L. N. Gumilyov Eurasian National University, Kazakhstan) and Zsombor Csata (Babeș-Bolyai University, Romania / Hungarian Academy of Sciences, Hungary).

(C) 2021 by the authors; licensee Cogitatio (Lisbon, Portugal). This article is licensed under a Creative Commons Attribution 4.0 International License (CC BY).

\section{Introduction}

Because participation in society is contingent upon labour market access, public employment services are central institutions regarding social equity, particularly in the context of migration-related diversity. When researching the Austrian Public Employment Service (AMS) and how it addresses linguistic diversity, we observed both the absence of a coherent institutional strategy and an ensuing shift of language management-related responsibilities onto individuals (see also Holzinger, 2020).

Globalisation and its ensuing superdiversity (Vertovec, 2007) require a reassessment of the articulation between language, migration, and institutions
(Duchêne, Moyer, \& Roberts, 2013). Despite its relative lack of attention in social science and migration studies (Canagarajah, 2017), the role of language has become more prominent in recent decades because of migration, new forms of mobility and transnationalism (Duchêne et al., 2013; Park \& Wee, 2017). Scholars have criticised superficial celebrations of neoliberal multiculturalism and multilingualism (Canagarajah, 2017; Flores, 2019), thus highlighting the need for more concentrated research into the specific political, economic, cultural and social processes through which (linguistic) difference is transformed into inequality (Brubaker, 2014).

In an increasingly mobile world, the organisation of social security faces new challenges (Sabates- 
Wheeler, Koettl, \& Avato, 2011). Additionally, migrants within the EU-where a unique transnational social security system has been established-face substantial barriers when accessing welfare-related services and resources (Scheibelhofer \& Holzinger, 2018; Scheibelhofer, Holzinger, \& Regös, 2020; Seeleib-Kaiser \& Pennings, 2018). For example, studies from Germany and Austria have shown that the enforcement of German as the language of administration and communication is the main informal barrier in this regard (Holzinger, 2020; Ratzmann, 2018). As Sabaté Dalmau, Garrido Sardà, and Codó (2017, p. 558) argue, migrants' access to key services for transnational survival "hinges upon the mobilization of 'appropriate' linguistic and communicative resources." Thus, language is at the core of migrants' unequal opportunities in how they organise their transnational lives (Sabaté Dalmau et al., 2017, p. 560).

Rather than merely being a neutral means of communication, language also serves to reproduce social inequalities on a symbolic level (Bourdieu, 1982). This social function of language is particularly relevant in the context of multilingual migration societies, where the phenomenon of transnationalism (Szanton-Blanc, Basch, \& Glick Schiller, 1995) characterises both the lives of those who are actively in the process of migrating and adjusting to a new place, and those who are native to or have lived there for a long time. Within the context of globalisation and the new economy, the link between language and national identity has been weakened by the promotion of global languages and the commodification of language (Duchêne \& Heller, 2012; Heller, 2010). At the same time, essentialist ties between language and national identity still serve as an influential model in the context of transnationalism (Park \& Wee, 2017). This complex relationship between language, the nation-state and transnationalism is of particular relevance in an EU context, where pro-linguistic diversity discourses contrast with the territorial organisation of linguistic difference and where de facto multilingual nation-states still perceive themselves as essentially monolingual (Busch, 2009; Gal, 2006; Stevenson, Mar-Molinero, \& Hogan-Brun, 2009).

Street-level bureaucracies, which occupy a frontline position in the mediation between government policy and the public (Lipsky, 1980), face unique communication challenges related to migration-induced linguistic diversity. As they function as both sites of migrant group categorisation and the administration of access to resources and services, a focus on public institutions provides insights into how social inequalities are (re)produced. Although contradictory ideologies and practices concerning language can arise in streetlevel bureaucracies, traditional ideologies that connect a national language with institutional identity are still influential in public institutions (Duchêne et al., 2013).

Drawing theoretically on Foucault, scholars working on the nexus of migration and language have shown that through everyday institutional practices, neoliberal governmentality affects how language is seen, used and governed (Martín Rojo \& Del Percio, 2019). Monolingualism-as a norm in institutional settings, rather than resulting from top-down policies-is often imposed by 'self-governing' strategies and monoglossic language ideologies, which have become embedded within institutions (Flores, 2019). Workfare (or activation), which emerged in the 1990s, can also be considered a form of governmentality (Flubacher, Coray, \& Duchêne, 2016). The internalisation of dominant discourses promoting the ideal of an 'entrepreneurial self' leads neoliberal subjects to regard social risks such as unemployment as their own responsibility (Soysal, 1994).

Discourses unfold in particular discursive spaces or fields, where they are institutionalised and operationalised by social actors (Allan, 2018). As street-level bureaucrats (Lipsky, 1980), AMS employees must handle diversity-related issues when interacting with clients and are responsible for implementing migration- and integration-related policies on a local scale. Research has shown that preconceived notions held by street-level bureaucrats about migrants can affect the services they receive (Schütze, 2019).

\section{Research Methodology}

The analysis in this article is based on findings from the ongoing qualitative research project AMIGSEmployment Services in the Context of MigrationInduced Linguistic Diversity. Using the AMS, the project investigates public institutions in the context of linguistic diversity. Commissioned by the Federal Ministry of Labour, the AMS-which is organised as an enterprise under public law-is tasked primarily with delivering labour market-related services for both companies and jobseekers. Most of our interviewees were advisors responsible for assisting job seekers with accessing information and training opportunities, as well as accessing financial support.

Vienna (Austria) was chosen because of how the AMS is structured federally, as well as the city's significantly higher share of migrants and migration-related linguistic diversity compared to the rest of the country (Statistik Austria, 2020).

Our previous research (Holzinger, 2020; Regös, Holzinger, \& Scheibelhofer, 2020; Scheibelhofer \& Holzinger, 2018; Scheibelhofer et al., 2020) identified difficulties in handling linguistic diversity-both among AMS clients and within the institution itself-which are evident in the language barriers and pressure experienced by street-level bureaucrats (Lipsky, 1980). In a previous study (Holzinger, 2020) we included input from the AMS' migrant clients and will additionally focus on their perspective in a future research project (the FWF Austrian Science Fund-financed project "Investigating the Social Construction of Deskilling Among 'New' EU 
Migrants in Vienna"). The ongoing project, however, is concerned with the internal perspective found within the institution; it investigates how AMS staff perceive handling linguistic diversity in their daily work routines as well as the associated problems and (both institutional and individual) solution strategies they describe. Thus, in order to focus on the latent structures, meaning-making processes and individual (coping) strategies at the AMS, our research employed a qualitative-interpretative approach. By drawing on the methodological principles of constructivist grounded theory (Charmaz, 2006, 2014) we collected data from problem-centred qualitative interviews (Scheibelhofer, 2008; Witzel \& Reiter, 2012) and ethnographic observations (Spradley, 2009). To grasp the diversity of views within the AMS, we are continuing to interview employees at different organisational levels and consulting units in Vienna. The data analysis is geared towards initial and focused coding techniques, as proposed by Charmaz $(2006,2014)$.

At the time of this article's completion, the project's first research cycle has concluded and 15 qualitative interviews have been conducted. Additionally, the following research draws on nine interviews with AMS employees from our previous studies. In total, our analysis is thus based on a heterogeneous sample of 24 interviews with AMS employees, of which ten were conducted at the management level (federal office, regional office of Vienna, regional branch offices and department managers), and fourteen with street-level bureaucrats from seven different regional branch offices (basically corresponding to Vienna's districts) as well as two specialised departments (counselling young clients, counselling convention refugees and people granted subsidiary protection). They ranged from 50 minutes to two hours, with an average length of 75 minutes. Almost half of the interviewees were 'lifeworld multilingual' (Gogolin, 1988) in languages such as Albanian, Dari, Farsi, French, Hungarian, Italian, Pashtu, Polish, Portuguese, Serbian, Spanish and Swedish, due to the participants' personal or family history of immigration. All interviewees learned English at school, as is common in Austria, while some learned additional languages such as French or Spanish.

The following results demonstrate the divergent approaches to multilingualism, as expressed by the interviewees through the argumentations and problematisations they raised when discussing their work. This range of perspectives can be understood by the simultaneous presence of various ideas about public institutions and language policies. These ideas, in turn, influence the practices of street-level bureaucrats in their meetings with clients, and should be interpreted within a context marked by both underfunding and neoliberal logic.

\section{A Monolingual Institution in a Multilingual Social Context?}

Before proceeding to the interview results, the following passage contains a brief observation we made about the
AMS website, which exemplifies the institution's stance on languages:

From www.ams.at (last accessed July 23rd, 2020): Here you can find German-language information about the first steps to take in the case of unemployment, further training opportunities, as well as working in Austria and the EU. At the top of the website, there are easy-to-understand options that demonstrate how to enlarge the font size for better accessibility. One looks in vain for one or more little symbols (e.g., flags or other signs) indicating the option to switch languages. However, only after scrolling down to the bottom of the page, below the Impressum (legal notice), do the two words "English version" appear. They can be found in the very last line, next to the privacy settings, and in an inconspicuously small font size. Our expectations for accessing the English version of the homepage by clicking on this option are immediately disappointed: Embedded in the German version of the webpage, there are only two sections translated into English, that give a very basic overview of the AMS and the services it offers (which make no mention about its responsibility for delivery of unemployment benefits). Overall, this is very scarce information. While further browsing through the German version of the homepage, we stumbled upon a handful of downloadable leaflets in other languages. We are puzzled: How can anyone lacking fluency in German access information on what to do in the case of unemployment?

Just like this brief evidence from the field, much of our empirical data clearly shows a contradictory relationship between the AMS and the realities of Vienna when it comes to how different languages are used within the city. Why would an unemployment agency in a highly diverse capital not offer this crucial information in other languages? How can we describe the deeper logics behind such evidence?

With approximately two million inhabitants, Vienna is a relatively small city compared to other European or international capitals, yet it is highly diverse: In 2019, more than $45 \%$ of the city's population had a migration background, most of whom spoke a first language other than German. Of the Austrian population with a migration background, more than two thirds had a first language other than German in 2014, and $17 \%$ had no or only very limited knowledge of German (Fuchs et al., 2019; Statistik Austria, 2020). Increasing diversity can also be noted in the labour market, where the share of non-nationals in the workforce grew significantly over the past decade (Auer, Grieger, \& Wach, 2019). To illustrate the linguistic diversity amongst those needing support from the AMS in Vienna, the employment rate for immigrants in Vienna who obtained their education in non-EU states was $56 \%$ in 2016 . This employment rate has been declining considerably since 2011 . By con- 
trast, the rate of employment in Vienna for non-Austrian, EU/EFTA-born citizens who obtained an Austrian education is 78\% (König et al., 2017). Furthermore, a positive correlation between German language skills and employment prospects has been observed (Gächter, 2016).

When approaching AMS employees at different hierarchical levels, we were astonished throughout our empirical work at how openly welcome our research interest in languages and everyday language use at the AMS was. We found a highly reflective environment in terms of diversity and language usage and were successful in securing interviewees in a short period of time. In fact, after word got around about our research topic, we were contacted by the interviewees in higher numbers than we had expected. Therefore, we were not surprised with how the interviewees usually started the interviews by describing how language and linguistic diversity was one of the most salient topics characterising everyday work at the AMS.

The participants' enthusiasm to participate in the interviews and their first-hand experiences, thus, sharply contrasted with what the AMS website projects. On the one hand, advisors highlighted the importance of using different languages as part of their work routines and were eager to share their experiences with linguistic diversity. On the other hand, the website almost completely ignored the multilingual reality of the Viennese labour market and thus failed to provide information that would be helpful to unemployed persons with limited knowledge of German language. In the following, we will use results from the still-ongoing analyses of our research materials to try to make sense of these observed divergences.

\subsection{Language-Related Difficulties for Street-Level Bureaucrats Amplified by Underfunding and New Public Management}

Institutional and political arrangements within the AMS help explain how languages manifest as everyday work issues, and how they are approached. Our findings differentiate between the following issues, which are sometimes directly addressed by the interviewed AMS employees. At the beginning of the interview, AMS officers would generally acknowledge that "customers" the term the AMS uses to address unemployed personsfrequently do not speak German as their first language. Thus, dealing with language-related issues is a common experience for the organisation's employees. Consequently, many AMS advisors expressed doubts about whether their clients would be able to understand what they told them, and the resulting misunderstandings might have implications for their eligibility for unemployment benefits. One interviewee expressed this concern as:

The question is always whether you've understood one another. I'm often not sure whether my cus- tomers understand me correctly. [Laughs] And if you then have somebody sitting in front of you who only speaks broken German, then naturally it's even more difficult. (Cornelia Nowack, advisor-all interviewee names have been anonymized)

After establishing the presence of language-related difficulties at their work, the clerks focused on coping strategies concerning how to manage situations where clients had very limited knowledge of the German language. For example, they would use simple expressions, while avoiding technical legal terms and elaborate German. When encountering their clients, the interviewees also found it helpful to create drawings or highlight written documents in different colours. Overall, we identified a wide and often disjointed variety of strategies, ranging from communicating with gestures to using technologies (e.g., pilot testing online interpretation via video).

A key issue for AMS officers was how to make themselves clear in terms of legally binding restrictions, which has many implications. It is ultimately the AMS officer's duty to provide legally flawless information to the unemployed. Therefore, trying to greatly simplify often-complex issues may interfere with their work duty. To avoid legal complications, AMS officers sometimes used additional coping strategies. At some local offices, interviewees who did not share a room with other colleagues described leaving their office door open. This ensured that their next-door colleague could listen in and serve as a witness if legal troubles later arose.

However, this issue of liability must be seen in a broader context. In addition to needing to communicate complex issues in simpler language, officers also must do so under specific circumstances that exacerbate language barriers. Our empirical work indicates that the specific institutional work context at the AMS is characterised by bureaucratic reform processes under the heading of new public management (see, e.g., Lessenich, 2015; Soysal, 2012) as well as chronic underfunding and understaffing arising from a combination of rising unemployment rates and cutbacks. The interviewees perceived high pressure concerning temporal, financial and personnel resources, in addition to considerable legal complexity and bureaucratisation. As noted by Penz, Sauer, Gaitsch, Hofbauer, and Glinsner (2017) in their comparative study, Austrian AMS advisors must juggle more legal fields than those in similar positions in Germany and Switzerland. Furthermore, they have a significantly higher caseload and thus only very short and standardised appointment timeslots. High and increased work requirements are accompanied by high levels of discretion and are regulated by constant performance evaluations for individual AMS employees and regional branch offices (Penz et al., 2017). Thus, explaining complex legal matters in an intelligible and accessible way to those with poor German skills requires time that employees rarely can provide. 
During our interviews, we noted how AMS clerks at different organisational levels had internalised the problem of limited resources. Such limitations induce street-level bureaucrats to carefully estimate the costs and benefits of each training measure for job seekers. For example, while following institutional guidelines, AMS employees had to quickly evaluate whether or not someone's employment prospects would benefit from German courses, which meant that typically only highly educated jobseekers with good employment outlooks were placed in higher-level courses. In the following quote, an advisor expresses regret about not being able to offer to all interested clients a higher-level German course due to limited resources and the AMS' focus on (re)integrating clients into the labour market as quickly as possible:

I also don't think it's a disadvantage if customers want to be trained above the B1 level. I wish they would also get it. But of course, all that costs money and the AMS is assigned to connect people and work and to do so as quickly as possible. And the fact is that with B1, which is approximately the level of compulsory education-having completed compulsory education-you can absolutely take up work in the auxiliary sector or to do an apprenticeship. (Lisa Gruber, advisor)

Additionally, the notion of self-responsibilization plays a role, including estimations about whether a client is sufficiently 'active' (i.e., self-motivated) in seeking a new job (Soysal, 2012). As one advisor explained:

So, these are the things where we...when we think about further support measures, whether we should really support the customer or...or not. Even if he meets the requirements, but his personal attributes wouldn't fit...then this support measure was in vain....And communication from the other side is also very important for us. How does the customer talk to me? Does he come and go or...does he have a certain amount of initiative, is seeking employment, has made an application, has submitted everything in writing. And...he needs assistance and then I have to act. (Farid Ahmadi, advisor)

This quote illustrates how some advisors internalized dominant discourses promoting 'self-responsibility' and how, therefore, the activation paradigm within European labour market politics (van Berkel, de Graaf, \& Sirovátka, 2012) functions as a form of governmentality. In such an environment, it is ultimately the AMS officers who make decisions that determine the future work biography of the unemployed. Thus, AMS officials have considerable leeway in their decision-making, which is characteristic of street-level bureaucrats (Lipsky, 1980). On one hand, this discretion is necessary for the advisors to cope with their complex and highly diverse caseload. On the other hand, this discretion may lead to additional strain for street-level bureaucrats, while being an additional source of unequal treatment and (linguistic) discrimination for clients, as admitted inter alia in the following quote from an AMS advisor:

It certainly is rather different from advisor to advisor, so to speak...assessing is one thing and partlywe may have our guidelines-but partly we also have some leeway. So...it is then a bit of a coincidence, so to say, which advisor you end up with and whether this advisor is a bit understanding and says, "ok, then let's do another German course," or eventually says, "well...yet another...a fourth German course, that doesn't make sense anymore, we are now only looking for jobs on construction sites," to put it in extreme terms. (Michael Tomek, advisor)

\subsection{Using Languages Other than German: An 'Emergency Solution' Only?}

Returning to the matter of which coping strategies AMS officers apply, interviewees also mentioned using one's own language repertoire beyond German. This was usually described as an 'emergency solution' used only when there was no other way to communicate. It was clear that switching to another language is not an everyday habit of AMS employees. However, interviewees explained that in exceedingly rare cases, when deemed necessary, they would speak in another language-usually English. However, this raises the question of what constitutes a 'necessity' to use another language in this context.

First, there were groups that the interviewees consistently referred to as vulnerable groups, thus legitimising their distinct treatment (which included language practices) that is inconsistent with the abovedescribed discourse on self-responsibilization. By contrasting them with unemployed migrants from the EU (who were described as independent, self-sufficient, and consequently not in need of institutional help), refugees were described as vulnerable and in need. As one regional branch director illustrated: "It's also evident that these people can't come here and function like well-situated Central Europeans" (Karl Metzler). In 2017, this recurrent pattern of reasoning justified using multilingual material and the creation of a special service point for refugees in Vienna, in which the AMS began to offer appointments in the first-languages of certain refugee populations. Specific material, trainings, or appointments in languages other than German were also offered to other groups. For example, women (mainly Muslim) were positioned as vulnerable and thus in need of 'special' treatment, including linguistic accommodations.

A further differentiation in how foreign languages were used at the AMS arose between officials who drew on languages they learned after childhood, mainly standard school languages, and native speakers of common migrant languages (such as Turkish or Bosnian- 
Croatian-Serbian). Implicitly, a special and simultaneously ambiguous status was afforded to the latter (in detail see Holzinger, 2020): Although non-German counselling is not legally prohibited by the AMS, it was presented as undesirable. Interviewees described how this viewpoint was transmitted verbally by department managers and colleagues as well as through daily institutional routines. However, the interviewees also reported occasionally relying on multilingual officials to provide unofficially valuable (and necessary) services concerning language-related problems. In this regard, interviewed executives explicitly addressed the problem of exploited native speakers (De Jong, 2019). For example, an interviewed director from a regional branch referred to native speakers of common migrant languages as "colleagues we somehow can exploit a bit if we need information" (Karl Metzler).

However, we also identified differences among interviewees who were themselves native speakers of languages other than German. While they all explained that they do most of their work in German, there was significant discrepancy regarding how they evaluated speaking another language and their reported practices-another paradigmatic example of the street-level bureaucrat's leeway in decision making. Some enjoyed using other languages in their line of work: "Well...so, my advantage is that I can switch. If Poles would come, I could absolutely see to it that I could help them along" (Lucjan Wisniewski, advisor). On the other hand, others were concerned about problems that could arise from communicating with clients in other languages. As one young female advisor expressed:

And I happen to have Serbian as my mother tongue; I actually don't use it at work-I avoid it. It's not really desirable, because first-because the customerswe see to it that the customers, if possible, learn to speak German. And second, simply, just for my selfprotection. (Dunja Ivanovic, advisor)

A recurrent theme in the interviews, as illustrated above, was the patronizing idea (in contrast to the notion of autonomous clients, according to the activation paradigm) that clients must be compelled to learn German and that communication in any other language will impede this goal. Advisors also frequently emphasized the need to be protected or protect themselves from potential 'fraternisation' among co-ethnics or clients' attempts to ensure favourable treatment based on an assumedly shared cultural identity. Besides the ensuing need to establish linguistic boundaries with clients to deter such illicit requests, (self-)protection was also mentioned regarding issues of hierarchy, power relations, and their intersection with languages. Communication in an institutional setting like the AMS entails establishing a certain power relation, to ensure that the street-level bureaucrats' role is respected in the subsequent interactions. As Bourdieu (1982) asserts, language is a fundamental means of negotiating social power positions. In that sense, using languages other than German at the AMS was perceived by most interviewees as a potential threat to maintaining a dominant speaker position-both for native speakers of nonGerman languages and, as the following passage shows, for those advisors reverting to languages acquired later in life, most notably English:

Of course, it's also that I have colleagues who don't speak foreign languages; now, they could not at all hold, uhm, a conversation in another language. Like I said, I myself also find it difficult, in English, because I often, need to use technical terms, so, I often find it awkward when I'm sitting there, in front of me....So, I was really embarrassed last time around, a young Syrian was sitting in front of me speaking perfect English and I was trying to explain something to him, and I couldn't express what I meant, so...that's, that's really, so....Perhaps you also don't do it so that you....Because I prefer to do it with an interpreter-the counselling interviews-because I myself am embarrassed that I often can't explain it. (Cornelia Nowack, advisor)

Interestingly, we identified some differences among AMS employees in their attitudes to multilingual communication and could partly link them to status positions. First, there were differences regarding the language in question: Speakers of more prestigious languages (such as English or Italian) were more inclined to use them than speakers of common migrant minority languages that enjoy less prestige in the Austrian context, such as Serbian or Hungarian. However, we also found decisive differences among speakers of these minority languages (see, for example, the above-mentioned Polishspeaking advisor). Second, our data indicates that interviewees' choice of which language to use during appointments is a resource that helps street-level bureaucrats gain legitimacy in their professional role as well as their client's compliance: For example, the above-mentioned young female Serbian-speaking advisor described how she often found it difficult to establish a professional relationship with her clients because they would not accept her position due to her age and gender-especially if they shared the same native language. Thus, insisting on using German helped her demand respect and maintain a professional distance.

In general, setting boundaries with clients seems to be important to AMS employees, especially under the challenging working conditions that are typical to the neoliberal restructuring of the welfare state. Nevertheless, it is essential for street-level bureaucrats to ensure a certain level of trust and cooperation with the unemployed (regardless of their first language). In order to reach the new public management goals in terms of management by objectives (Weishaupt, 2010), employees must perform affective work (Penz et al., 
2017). This emotional work is even more complex if additional languages are incorporated into the situation. In the following passage, an AMS officer described the difficulties that arose in her work arising from the (assumed) intersection of deficient German language skills and the lack of willingness to cooperate:

To generally understand the preconditions, 'what do I actually have to fulfil?' For a start, in order to receive a benefit, that's actually the most difficult barrier; then it's most often that the customers don't wantnot that they don't know it-but rather that they don't want. But at the beginning, it's just really hard, it's hard to rate. Does she get me now and simply doesn't want to have it that way? Or does she not get me and is just defending herself, so to speak, because she can't do it otherwise, can't express it another way? (Dunja Ivanovic, advisor)

The AMS officers described their tasks not only in terms of emotional work in order to ensure cooperation on the side of the unemployed. As with previous examples, this quotation also shows how power relations are negotiated through language use. In this case, we can see how advisors perceive resistance from some clients who they suspect to 'hide' behind (ostensible) incomprehension.

\subsection{Speaking German as the Dominant Strategy}

As described in the preceding sections, all interviewees acknowledged a multiplicity of languages present in their everyday work. However, our analyses show that the AMS as an organisation is predominantly perceived as a monolingual institution. This is maintained by the assumption that the Viennese labour market is Germanspeaking, meaning the unemployed must speak German to find work. Therefore, the AMS may ask its clients to communicate in German. The interviewees also argued that they did not want to send false signals and pointed to an assumed unwillingness to learn German on the part of their clients, thereby drawing on widespread public and political discourses concerning language and integration (Cederberg, 2014; Cillia \& Dorostkar, 2013; Flubacher, 2018; Flubacher et al., 2016; Plutzar, 2010). Another common overtone that highlights the AMS being perceived as monolingual is the normative role of German in everyday work: In 14 of the 24 interviews, the interviewees stated (without being prompted) that the 'official' or 'administrative language' (Amtssprache) of the AMS is German. Amtssprache has a clearly normative connotation, and its emphasis from the interviewees indicates the influence of a traditional ideology that connects a national language with institutional identity.

Nevertheless, it should be emphasised that the interviewees also reflected upon the monolingual (self-)image of the organisation, by mostly applying a temporal lens to the meaning of the German language within the AMS. The following interviewee stressed that younger, more diverse colleagues would put their first languages to use as well:

The first thing you'd learn is: German is the Amtssprache in Austria. That was in me, as well. OK? Simply, if you hear it all around, then that's the way it is. OK? And I still hear myself frequently saying, I'm certainly not going to speak English, German is the official language in Austria. So....And that's changed though. Thank God that's changed. I believe it's a, a question of generations. We've really got a lot of young colleagues...who just don't see it that way. Who use their Turkish, who use their Serbian, whatever we've got as to languages. (Theresa Lenz, department head)

Thus, we could identify ideas and ideologies which contested the traditional idea of German as the only legitimate institutional language by recognizing the multilingual reality of Vienna and valuing multilingualism. However, although interviewees acknowledged (increasing) diversity-including diversity of language usewithin the AMS, we see that monolingualism remains dominant. This becomes most obvious in one of the few documents addressing language usage at the AMS: In the event that unemployed persons who at their first appointments seem to speak German insufficiently, they are handed a double-sided, printed information sheet stating in 20 languages to take someone who can interpret for them along to their next appointment. As a justification for the necessity of monolingualism, the interviewees repeatedly told us that they needed to make sure that they could flawlessly provide legally binding information, as described earlier. Thus, by asking the unemployed to bring interpreters to the appointments, street-level bureaucrats can avoid being blamed for misunderstandings, while the need for (language-related) problem-solving is delegated to the unemployed person seeking assistance from the AMS (see also Holzinger, 2020). Nevertheless, this organisational strategy does not guarantee that the correct information reaches the clients, since those interpreting may speak German only slightly better than the clients themselves. Additionally, the concept of self-responsibility is once again invoked here to relieve the AMS of its responsibility to ensure mutual understanding:

Yes, because the responsibility always lies with the customer and they have to make sure that they understand it. It's like when you go abroad, then you have to find out for yourself what the rules are like abroad. Yes, the legal requirements, for example.....Yes, it is the self-responsibility of the customer to understand what we are saying here; we cannot speak all the languages of the world. (Lisa Gruber, advisor)

The observed top-down instructions, official guidelines and regulations thus point to monolingualism as the main strategy used to cope with diversity at this institution. 


\section{Conclusion}

Returning to our vignette of the AMS website above, we now can provide more clarity about the context surrounding a website directed at all unemployed persons living in Austria that is clearly not equipped to provide information in any language besides German. We could not discern a coherent AMS-wide institutional strategy regarding linguistic diversity. Instead, streetlevel bureaucrats have considerable leeway in decisionmaking regarding language use. While we identified monolingualism as the main strategy, multiple multilingual practices can be identified in the everyday work of AMS employees, yet they reflect a disorganised mix of side strategies rather than a coherent institutional strategy. We explained this apparent incongruity in the copresence of various (occasionally conflicting) ideologies and ideas about languages and language use. These, in turn, influence the practices of street-level bureaucrats in a context marked by scarce resources and new public management reforms.

We therefore argue that diverging strategies, ranging from monolingual to multilingual, can be readily combined with each other. Both ends of this linguistic continuum must be recognised as existing within a changing political and public discourse as well as based on neoliberal activation policy. While we encountered contradictory ideologies and practices concerning language when researching the AMS, we also observed that traditional ideologies, connecting a national language with institutional identity, are still influential in this public institution (Duchêne et al., 2013).

We conclude that more interpretative qualitative research is necessary to provide a more detailed account of the complex, interwoven issues as well as simultaneous monolingual and multilingual practices within a single institution. In the context of de facto multilingual nation states, which paradoxically still perceive themselves as essentially monolingual (Busch, 2009; Gal, 2006; Stevenson et al., 2009), we advocate for contemplating about these issues in more general terms: Looking at street-level bureaucracies in general, such as unemployment services, in addition to hospitals, schools or universities, may reveal a greater phenomenon of neglecting linguistic diversity as an issue for the respective organisation, which requires a coherent institutional answer. In other words, dealing with language barriers and communication problems is still too often delegated to the individual street-level bureaucrats. In turn, their primary focus-especially in a context of neoliberal management strategies and underfunding -is rather on delivering what they are trained to, whether it involves reintegrating people into employment, helping them improve their health, or learning necessary skills, rather than on ensuring equal access to resources for all clients regardless of their linguistic resources.

As highly diverse societies, we will need to further develop approaches to overcome language-based dis- crimination and power struggles that lead to associated social inequalities. Achieving this requires much more interdisciplinary and internationally comparative work to move beyond unchallenged traditional ideas about language usage that reflect social inequalities not only within the researched organisation but within society in general.

\section{Acknowledgments}

The two-year research project AMIGS (2019-2021) was funded by the Anniversary Fund of the Central Bank of the Republic of Austria (OeNB, Project Number 18078). Open access funding was provided by the University of Vienna. We thank the three anonymous reviewers for their helpful comments on earlier drafts of the manuscript.

\section{Conflict of Interests}

The authors declare no conflict of interests.

\section{References}

Allan, K. (2018). Critical political economic approaches to the study of language and neoliberalism. Journal of Sociolinguistics, 22(4), 454-469. https://doi.org/ 10.1111/josl.12313

Auer, E., Grieger, N., \& Wach, I. (2019). Erstmals mehr als 4 Millionen Menschen: Wie sich das Arbeitskräftepotenzial zusammensetzt und wie sehr es sich in den letzten 10 Jahren verändert hat [For the first time: More than four million people. What the labour force potential is composed of and how strongly it has changed over the past 10 years]. Vienna: Public Employment Service Austria, Department of Labour Market Research and Career Information.

Bourdieu, P. (1982). Ce que parler veut dire: L'économie des échanges linguistiques [Language and symbolic power]. Paris: Fayard.

Brubaker, R. (2014). Linguistic and religious pluralism: Between difference and inequality. Journal of Ethnic and Migration Studies, 41(1), 3-32.

Busch, B. (2009). Local actors in promoting multilingualism. In G. Hogan-Brun, C. Mar-Molinero, \& P. Stevenson (Eds.), Discourses on language and integration: Critical perspectives on language testing regimes in Europe (pp. 129-152). Amsterdam: Benjamins.

Canagarajah, S. (2017). The nexus of migration and language. The emergence of a disciplinary space. In C. Suresh (Ed.), The Routledge handbook of migration and language (1st ed., pp. 1-28). London: Routledge.

Cederberg, M. (2014). Public discourses and migrant stories of integration and inequality: Language and power in biographical narratives. Sociology, 48(1), 133-149.

Charmaz, K. (2006). Constructing grounded theory: $A$ practical guide through qualitative analysis. Thou- 
sand Oaks, CA: SAGE.

Charmaz, K. (2014). Constructing grounded theory (2nd ed.). London: SAGE.

Cillia, R. d., \& Dorostkar, N. (2013). Integration und/durch Sprache [Integration and/through language]. In J. Dahlvik, C. Reinprecht, \& W. Sievers (Eds.), Migration und Integration-Wissenschaftliche Perspektiven aus Österreich [Migration and integrationScientific perspectives from Austria] (pp. 143-162). Göttingen: V\&R Unipress.

De Jong, S. (2019). A window of opportunity? Refugee staff's employment in migrant support and advocacy organizations. Identities, 26(3), 321-338.

Duchêne, A., \& Heller, M. (Eds.). (2012). Language in late capitalism: Pride and profit. London: Routledge.

Duchêne, A., Moyer, M., \& Roberts, C. (2013). Introduction: Recasting institutions and work in multilingual and transnational spaces. In A. Duchêne, M. Moyer, \& C. Roberts (Eds.), Language, migration and social inequalities: A critical sociolinguistic perspective on institutions and work (pp. 1-21). Bristol: Multilingual Matters.

Flores, N. (2019). Producing national and neoliberal subjects. Bilingual education and governmentality in the United States. In L. Martín Rojo \& A. Del Percio (Eds.), Language and neoliberal governmentality (pp. 49-68). London and New York, NY: Routledge.

Flubacher, M.-C. (2018). "Sprache," Integration und Arbeit. Eine soziologische Annäherung ["Language," integration and work. A sociological approach]. In S. Engelage (Ed.), Migration und Berufsbildung in der Schweiz [Migration and vocational training in Switzerland] (pp. 53-76). Zurich: Seismo.

Flubacher, M.-C., Coray, R., \& Duchêne, A. (2016). Language, integration, and investment: The regulation of diversity in the context of unemployment. Multilingua: Journal of Cross-Cultural and Interlanguage Communication, 35(6), 675-696.

Fuchs, R., Klimont, J., Knittler, K., Kytir, J., Marik-Lebeck, S., Wisbauer, A., \& Biffl, G. (2019). Migration und Integration 2019 [Migration and integration 2019]. Vienna: Statistik Austria.

Gächter, A. (2016). Die Attraktivität von Arbeitskräften aus den EU-Mitgliedsstaaten 2004 und 2007 [The attractiveness of labour from the EU member states in 2004 and 2007] (Working Paper No. 31). Vienna: Zentrum für Soziale Innovation.

Gal, S. (2006). Migration, minorities and multilingualism. Language ideologies in Europe. In C. Mar-Molinero \& P. Stevenson (Eds.), Language ideologies, policies and practices: Language and the future of Europe (pp. 13-27). London: Palgrave Macmillan.

Gogolin, I. (1988). Erziehungsziel Zweisprachigkeit: Konturen eines sprachpädagogischen Konzepts für die multikulturelle Schule [Bilingualism as an educational goal: Outlines of a language education concept for multicultural schools]. Hamburg: Bergmann + Helbig. Heller, M. (2010). The commodification of language.
Annual Review of Anthropology, 39, 101-114.

Holzinger, C. (2020). 'We don't worry that much about language': Street-level bureaucracy in the context of linguistic diversity. Journal of Ethnic and Migration Studies, 46(9), 1792-1808. https://doi.org/10.1080/ 1369183X.2019.1610365

König, K., Manolakos, T., Luger, K., Ganal, U., Häberlin, U., Akagündüz-Binder, B., . . . Fröschl, D. (2017). 4 Wiener Integrations \& Diversitätsmonitor 2013-2016 [Fourth Viennese integration and diversity monitor, 2013-2016]. Vienna: City of Vienna, Integration and Diversity (Municipal Department 17).

Lessenich, S. (2015). Die Neuerfindung des Sozialen: Der Sozialstaat im flexiblen Kapitalismus [Reinventing the social: The welfare state in flexible capitalism]. Bielefeld: transcript.

Lipsky, M. (1980). Street-level bureaucracy. New York, NY: Russell Sage Foundation.

Martín Rojo, L., \& Del Percio, A. (2019). Neoliberalism, language, and governmentality. In L. Martín Rojo \& A. Del Percio (Eds.), Language and neoliberal governmentality (pp. 1-25). London and New York, NY: Routledge.

Park, J. S.-Y., \& Wee, L. (2017). Nation-state, transnationalism and language. In C. Suresh (Ed.), The Routledge handbook of migration and language (1st ed., pp. 47-62). London: Routledge.

Penz, O., Sauer, B., Gaitsch, M., Hofbauer, J., \& Glinsner, B. (2017). Post-bureaucratic encounters: Affective labour in public employment services. Critical Social Policy, 37(4), 540-561. https://doi.org/ $10.1177 / 0261018316681286$

Plutzar, V. (2010). Sprache als "Schlüssel" zur Integration? Eine kritische Annäherung an die österreichische Sprachenpolitik im Kontext von Migration [Language as a "key" to integration? A critical approach to Austrian linguistic policies in the context of migration]. In H. Langthaler (Ed.), Integration in Österreich. Sozialwissenschaftliche Befunde [Integration in Austria. Social science findings]. Innsbruck: Studien Verlag.

Ratzmann, N. (2018). Gleichberechtigt-und diskriminiert. Für EU-Bürger gibt es Zugangsbarrieren zur deutschen Grundsicherung [Equitable-and discriminated. There are barriers to entering basic German security benefits]. WZ Mitteilungen, 159, 41-43.

Regös, E. N., Holzinger, C., \& Scheibelhofer, E. (2020). When vicinity divides: Transnational social security in the cross-border region of Hungary and Austria. In A. Amelina, E. Carmel, A. Runfors, \& E. Scheibelhofer (Eds.), Boundaries of European social citizenship. EU citizens' transnational social security in regulations, discourses and experiences (pp. 113-132). New York, NY: Routledge.

Sabaté Dalmau, M., Garrido Sardà, M. R., \& Codó, E. (2017). Language-mediated services for migrants. Monolingualist institutional regimes and translinguistic user practices. In C. Suresh (Ed.), The Routledge 
handbook of migration and language (1st ed., pp. 558-576). London: Routledge.

Sabates-Wheeler, R., Koettl, J., \& Avato, J. (2011). Social security for migrants: A global overview of portability arrangements. In R. Sabates-Wheeler \& R. Feldmann (Eds.), Migration and social protection. Claiming social rights beyond borders (pp. 91-116). Basingstoke: Palgrave Macmillan.

Scheibelhofer, E. (2008). Combining narration-based interviews with topical interviews: Methodological reflections on research practices. International Journal of Social Research Methodology, 11(5), 403-416. https://doi.org/10.1080/13645570701401370

Scheibelhofer, E., \& Holzinger, C. (2018). 'Damn it, I am a miserable Eastern European in the eyes of the administrator': EU migrants' experiences with (transnational) social security. Social Inclusion, 6(3), 201-209. https://doi.org/10.17645/si.v6i3.1477

Scheibelhofer, E., Holzinger, C., \& Regös, E. N. (2020). Navigating the labyrinths of transnational social security: Experiences and meaning-making processes of EU migrants when accessing and porting social benefits. In A. Amelina, E. Carmel, A. Runfors, \& E. Scheibelhofer (Eds.), Boundaries of European citizenship: Regulations, discourses and experiences of transnational social security (pp. 91-112). London: Routledge.

Schütze, C. (2019). Attitudes matter-Welfare work and migration in Sweden. Migration Studies, 8(3). https://doi.org/10.1093/mny/mny048

Seeleib-Kaiser, M., \& Pennings, F. (2018). Intra-EU migration and social rights: An introduction. In M. SeeleibKaiser \& F. Pennings (Eds.), EU citizenship and social rights. Entitlements and impediments to accessing welfare (pp. 1-7). Cheltenham: Edward Elgar.

Soysal, Y. N. (1994). Limits of citizenship: Migrants and postnational membership in Europe. Chicago, IL: Uni- versity of Chicago Press.

Soysal, Y. N. (2012). Citizenship, immigration, and the European social project: Rights and obligations of individuality. The British Journal of Sociology, 63(1), 1-21.

Spradley, J. P. (2009). Participant observation (31st ed.). Belmont, CA: Wadsworth, Cengage Learning.

Statistik Austria. (2020). Bevölkerung mit Migrationshintergrund nach Bundesländern (Jahresdurchschnitt 2019) [Population with migrant backgrounds according to federal states (2019 annual average); Press release]. Retrieved from http://www.statistik. at/web_de/statistiken/menschen_und_gesellschaft/ bevoelkerung/bevoelkerungsstruktur/bevoelkerung _nach_migrationshintergrund/index.html

Stevenson, P., Mar-Molinero, C., \& Hogan-Brun, G. (2009). Discourses on language and integration: Critical perspectives on language testing regimes in Europe. Amsterdam: John Benjamins Publishing Co.

Szanton-Blanc, C., Basch, L., \& Glick Schiller, N. (1995). Transnationalism, nation-states, and culture. Current Anthropology, 36, 683-686. https://doi.org/ 10.1086/204418

van Berkel, R., de Graaf, W., \& Sirovátka, T. (2012). Governance of the activation policies in Europe: Introduction. International Journal of Sociology and Social Policy, 32(5/6), 260-272. https://doi.org/10.1108/ 01443331211236943

Vertovec, S. (2007). Super-diversity and its implications. Ethnic and Racial Studies, 30(6), 1024-1054. https:// doi.org/10.1080/01419870701599465

Weishaupt, J. T. (2010). A silent revolution? New management ideas and the reinvention of European public employment services. Socio-Economic Review, 8(3), 461-486.

Witzel, A., \& Reiter, H. (2012). The problem-centred interview. London: SAGE.

\section{About the Authors}

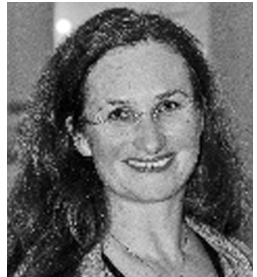

Elisabeth Scheibelhofer is an Associate Professor of Sociology (University of Vienna) working on migration, mobility and qualitative methods. She is currently leading the research project AMIGS (2019-2021) which is looking at labour-market institutions in multilingual societies. This is a followup project of a broader international collaboration (transwel.org; 2015-2018) covering EU migrants' transnational access to social security rights. She has published extensively on a range of issues within migration research and qualitative methodologies.

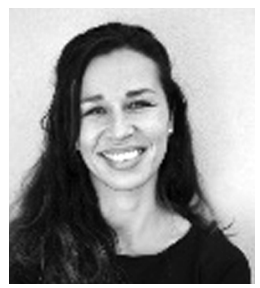

Clara Holzinger works as a Research Assistant and Lecturer at the Department of Sociology, University of Vienna, Austria. She is currently working on the AMIGS project (2019-2021). She has a disciplinary background in Sociology, Applied Linguistics and History. Her research interests focus on qualitative empirical methods, migration, welfare, linguistic diversity and language policy. Recent publications include the article "'We Don't Worry That Much About Language': Street-Level Bureaucracy in the Context of Linguistic Diversity" (2020; Journal of Ethnic and Migration Studies, 46(9), 1792-1808). 


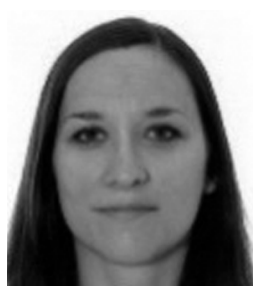

Anna-Katharina Draxl works as a Research Assistant at the Department of Sociology, University of Vienna, Austria. Having a background in Social and Cultural Anthropology and Applied Linguistics, she has experience in interdisciplinary research teams in Educational Studies and Sociology. Her research interests focus on migration and language in the fields of education, work and language policy. 